\title{
Platelet to Lymphocyte Ratio and Acute Appendicitis
}

\author{
Platelet Lenfosit Oranı ve Akut Apandisit
}

\section{Șahin Kahramanca', Gülay Özgehan², Oskay Kaya², İsmail Emre Gökce³, Tevfik Hadi Küçükpınar², Hülagü Kargıc'², Mehmet Fatih Avșar ${ }^{4}$}

${ }^{1}$ Kars State Hospital, Department of General Surgery, Kars; ${ }^{2} D_{\imath \xi}$ kapı Ylldrrm Beyazıt Training and Research Hospital, Department of General Surgery; ${ }^{3}$ Ulus State Hospital, Department of General Surgery; ${ }^{4}$ Numune Training and Research Hospital, Department of General Surgery, Ankara, Turkey

\begin{abstract}
Aim: Acute appendicitis $(A A)$ is a frequent condition for general surgery practice. However, sometimes there may be difficulties in accurate diagnosis. The aim of this study is to research the predictive value of platelet to lymphocyte ratio (PLR) in diagnosis of $A A$.
\end{abstract}

Material and Method: Hospital records were investigated retrospectively for 569 patients who underwent operation for AA diagnosis. According to postoperative histopathological examination of specimens, patients were divided into two groups: acute appendicitis group (G1) and normal appendix group (G2). Demographic analyses and PLR calculations on hospital admission were compared intergroup.

Results: There were 475 patients in $\mathrm{G} 1$ whereas 94 in G2. The cut-off value of PLR for diagnosis of AA was 136.5 ( $p=0.036)$. The sensitivity and specificity were $56.3 \%$ and $55.3 \%$ respectively. Positive predictive value and negative predictive value were found as $86.2 \%$ and $19.6 \%$ respectively.

Conclusion: PLR may be a valuable parameter supporting clinical evaluation for diagnosis and management of $A A$.

Key words: acute appendicitis; platelet to lymphocyte ratio

\section{ÖZET}

Amaç: Akut apandisit (AA) genel cerrahi pratiğinde sık karșılașılan bir durumdur. Ancak doğru tanıya ulașmada bazen zorluklar olabilmektedir. Bu çalıșmanın amacı AA tanısında platelet lenfosit oranının (PLO) belirleyiciliğini araștırmaktır.

Materyal ve Metot: Akut apandisit tanısı ile ameliyat edilmiș 569 hastaya ait hastane kayıtları geriye dönük olarak incelendi. Postoperatif histopatolojik inceleme sonuçlarına göre hastalar iki gruba ayrıldı: Akut apandisit grubu (G1) ve normal appendiks grubu (G2). Gruplar arasında demografik analizler ve PLO hesaplamaları karșılaștırıldı.

Sabin Kabramanca, Kars Merkez, Kars - Türkiye,
Bulgular: G1 de 475, G2 de 94 hasta vardı. AA tanısında PLO için sınır değer 136,5 $(p=0,036)$ olarak hesaplandı. Duyarlıık ve seçicilik sırası ile \%56,3 ve \%55,3 idi. Pozitif prediktif ve negatif prediktif değerler sırası ile \%86,2 ve \%19,6 olarak bulundu.

Sonuç: AA tanısında ve tedavinin yönlendirilmesinde PLO değerli bir ölçüt olabilir.

Anahtar kelimeler: akut apandisit; platelet lenfosit oranı

\section{Introduction}

Surgical management of acute appendicitis (AA) is one of the most commonly performed operations worldwide since its first description by Reginald Fitz in $1886^{1}$. However, there are some recent studies about medical treatment of the disease ${ }^{2}$. The lifetime occurrence of AA is $8 \%$; clinical presentation varies from mild to severe and mortal condition. Fortunately, mortality is less than $1 \%{ }^{3}$. Historically, management of the patient is based on typical history, physical findings, laboratory tests and imaging studies. Traditionally, negative appendectomy within reasonable limits is acceptable for fear of morbidity and mortality due to perforation. But today, it is not acceptable and in order to improve preoperative diagnosis and to avoid negative laparotomy many scoring systems were described ${ }^{4-6}$. The neutrophil to lymphocyte ratio (NLR) and platelet to lymphocyte ratio (PLR) are associated with worse outcome in various diseases. And NLR is one of the newest parameters for $\mathrm{AA}^{7,8}$. However we didn't find any other study that investigated platelet to lymphocyte ratio (PLR) for this purpose in English literature.

\section{Material and Method}

After approval of the hospital ethics committee a retrospective study was designed. The patients with AA 
diagnosis in preoperative period were evaluated from the hospital database. The demographic characteristics of patients, laboratory test results on admission to the hospital, operative findings and postoperative pathology reports were enrolled. The study was performed in 33 months period from January 2011 to September 2013. Initially there were 645 patients with these criteria. But 76 patients were excluded from the study because of comorbidities such as malign or haematological disorders, recent blood transfusion history and missing files. We determined that they had different problems except AA. Thus 569 patients were included to the study. The diagnoses of AA were obtained with traditional patient history, physical examination, routine laboratory and radiologic tests and sometimes imaging studies such as ultrasonography and computed tomography. The platelet and lymphocyte counts were measured by an automated hematologic analyzer (Coulter LH 780 Hematologic Analyzer, Beckman Coulter Inc. Brea, USA). The calculations of PLRs were done from these data at the time of patient admission.

Totally, data of 569 patients were analyzed. Pathology reports were used to determine whether the appendix was inflamed (catarrhal, suppurative or gangrenous) or normal. Normal appendix has not any pathologic change in mucosa. Catarrhal appendicitis has raised neutrophil in mucosa. Inflammatory changes involve muscular and subserosal layers in suppurative appendicitis. In gangrenous appendicitis, there are vessel thrombosis and necrotic areas in appendix wall. Patients were divided in two groups according to histopathology of the specimens: positive appendectomy group $(\mathrm{G} 1)$ and negative appendectomy group (G2).

Data analysis was performed by using SPSS for Windows, version 17.0 (SPSS Inc, Chicago, Illinois, USA). Whether the distributions of continuous variables were normally or not was determined by Kolmogorov-Smirnov $\mathrm{Z}$ test. Data were shown as mean \pm standard deviation or median (min-max), where applicable. Categorical data were analyzed by Pearson's chi-square test, where appropriate. The differences between groups were compared by using Mann Whitney U test or Student's T, where appropriate. The cut-off values of parameters for discrimination of the groups were determined using the ROC analysis. At each value, the sensitivity and specificity for each outcome under study was plotted, thus generating an ROC curve. A p value less than 0.05 was considered statistically significant.

\section{Results}

Data of 569 patients were analyzed. Negative appendectomy ratio was $94 / 569$ (16.5\%). Median age of analyzed group was $29(17-85)$ and $30.6 \%$ of the patients were female. There were 475 patients in G1 whereas 94 patients in G2. There were no significant difference between the groups according to age $(\mathrm{p}=0.658)$. In gender analyses female/male ratio was $128 / 347$ in G1 whereas $46 / 48$ in G2. Thus negative appendectomy rate was statistically higher in females $(\mathrm{p}<0.001)$. The findings were summarised in Table 1 . The median PLR values in G1 and G2 were 146.5 (59.7-975.0) and 123 (28.4-497.8) respectively. PLR values were significantly different intergroups ( $\mathrm{p}=0.036)$ (Fig. 1).

The recommended cut-off value of the PLR for positive and negative appendectomies was decided using receiver operating characteristic curve analyses. The recommended cut-off value of the PLR was based on the most prominent point on the receiver operating characteristic curve. This was 0.563 for sensitivity, 0.553 for specificity, 0.196 for negative predictive value (NPV) and 0.862 for positive predictive value (PPV). According to these four parameters the recommended PLR cut-off value was defined as 136.5. The area under the receiver operating characteristic curve was 0.568 (95\% CI 0.508-0.628 p: 0.036) (Fig. 2).

Table 1. Patients demographic characteristics

\begin{tabular}{lcccc}
\hline & Group 1 & Group 2 & & \\
& (positive appendicitis) & (negative appendicitis) & Total & $\mathrm{p}$ value \\
\hline Age (year) (median) (min-max) & $29(17-85)$ & $29(17-80)$ & $29(17-85)$ & $\mathrm{p}=0.658$ \\
Gender (F/M) (n) & $128 / 347$ & $46 / 48$ & $174 / 395$ & $\mathrm{p}<0.001$ \\
Patients ( $\mathrm{n})$ & 475 & 94 & 569 & \\
\hline
\end{tabular}

F; female, M; male 


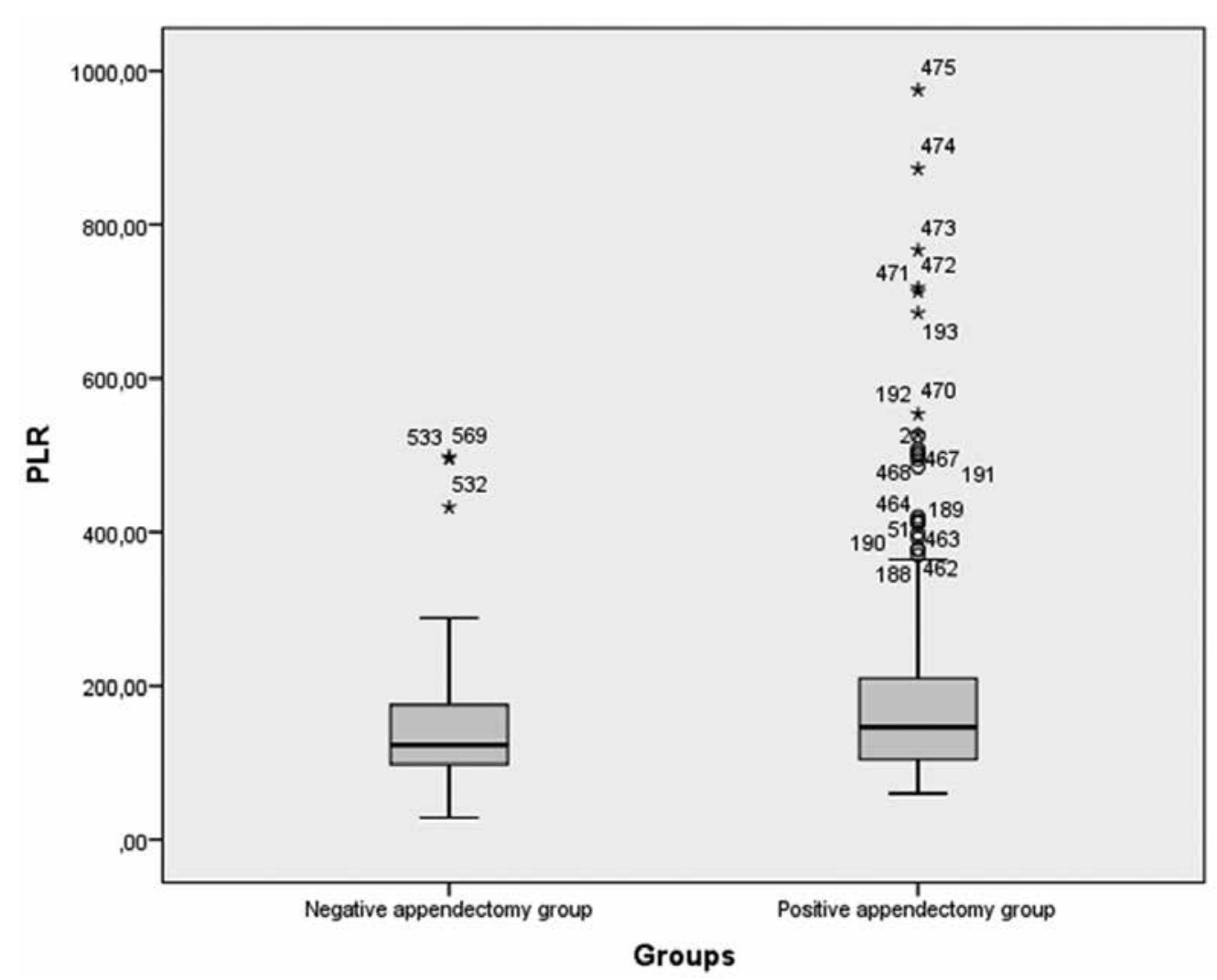

Figure 1. PLR distributions intergroups [PLR Group 1:146.5 (59.7-975.0), PLR Group 2:123.0 (28.4-497.8) and p=0.036].

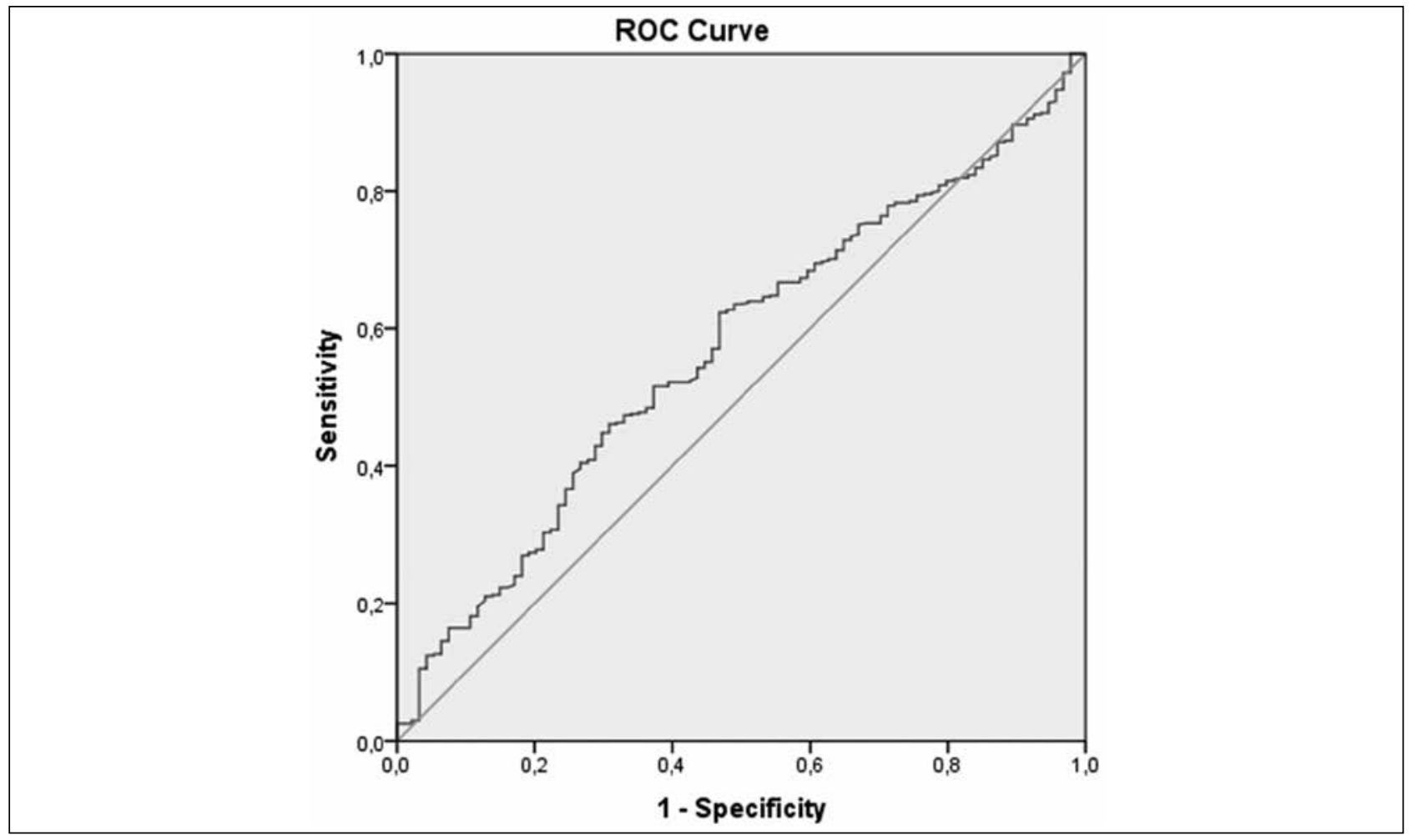

Figure 2. PLR ROC curve intergroups [Cut off value: 136.5, Area under the curve: 0.568; $p=0.036$ (Cl\% 95:0.508-0.628)]. 
Table 2. Multivariate COX regression analysis (Age, gender and PLR)

\begin{tabular}{ll}
\hline Independent factors & $\mathrm{p}$ values \\
\hline Age & $\mathrm{p}=0.295$ \\
Gender & $\mathrm{p}<0.001$ \\
$\mathrm{PLR}$ & $\mathrm{p}=0.011$ \\
\hline
\end{tabular}

PLR; Platelet Iymphocyte ratio

We found either of gender and PLO were independent factors to predict the complicated appendicitis when we investigated the joint role of them (Table 2).

\section{Discussion}

Appendicitis is one of the most frequent acute surgical conditions of the abdomen, and appendectomy is one of the most commonly performed operations in the world. Lee et al. reported that in their South Korean epidemiological study, the overall incidences of appendicitis, total appendectomy, and perforated appendectomy were $22.71,13.56$, and 2.91 per 10000 populations per year, respectively ${ }^{9}$. Today traditional management of AA is changed from strict surgical intervention to conservative therapies such as antibiotic use $^{2}$. No longer are negative appendectomies acceptable because operation itself is a cause of morbidity and mortality. In recent years there have been many efforts to improve preoperative diagnosis ${ }^{10}$. We need some simple, easy accessible and cheap extra methods in addition to conventionally obtained patient history, physical examination results and laboratory tests. A lot of scoring systems derived from these simple findings were defined ${ }^{4-6}$. Advanced imaging studies may be more helpful but they are expensive and difficult to supply especially in rural areas.

Lately NLR is defined and used for these purposes and as a marker of serious inflammation. Positive results were reported in the literature ${ }^{7,8,11}$. PLR is another marker like this and it was used in various clinical conditions to determine the degree of seriousness. In many types of cancer and inflammatory processes, the release of proinflammatory cytokines promotes magakaryocytes' proliferation. The activation of platelets is a hallmark in the natural course of cancer, by promoting neoangiogenesis, degradation of extracellular matrix, release of adhesion molecules, and growth factors ${ }^{12,13}$. Lee et al. demonstrated that NLR or PLR were independent prognostic factors for overall survival with advanced gastric cancer treated with chemotherapy ${ }^{14}$. Similarly PLR was found valuable for determination of prognosis in colorectal cancer as strong as NLR ${ }^{15,16}$. But He W. et all. found no NLR was superior to PLR in patients with metastatic colorectal cancer ${ }^{17}$. There are some studies about PLR and periampullary cancer in the literature but reports are not satisfactory ${ }^{18,19}$. There are valuable results in the studies about the role of PLR in terms of prognosis of the patients with breast and gynaecological malignancies ${ }^{12,13,20,21}$. The predictive values of PLR in patients with myocardial infarction, peripheral arterial occlusive disease, and end-stage renal diseases were also studied ${ }^{22-24}$. But we didn't find any study about PLR and AA in English Literature.

In our study we found significantly higher PLR values in positive appendectomy group (G1) than negative appendectomy group (G2) ( $p=0.036)$. The cut-off value of PLR was 136.5; sensitivity, specificity, NPV and PPV were $56.3 \%, 55.3 \%, 19.6 \%$ and $86.2 \%$, respectively. The low values may be explained by that only the operated patients were included in this study, data about other suspected cases which were not operated or medically treated were unknown. In gender analyses female/male ratio was $128 / 347$ in G1 whereas 46/48 in G2. Thus negative appendectomy rate was statistically higher in females $(\mathrm{p}<0.001)$. This may be because of gynaecological diseases commonly mimicking acute appendicitis.

In this study, PLR was found a reliable parameter to distinguish AA when its value was higher than the cutoff value (136.5). There is a need for more prospective randomised studies to find ideal PLR cut-off values. It seems that quests for the ideal test should continue and the surgeon' $s$ experience will still have the biggest importance.

\section{References}

1. Fitz RH. Perforating inflammation of the vermiform appendix, with special reference to its early diagnosis and treatment. Trans Assoc Am Physicians 1886;1:107-44.

2. Andersson RE. The role of antibiotic therapy in management of acute appendicitis. Curr Infect Dis Rep 2013;15(1):10-3.

3. Maa J, Kirkwood KS. The appendix. In: Townsend CM (ed). Sabiston Textbook of Surgery 19th edition, Sounders Elsevier Inc. Philadelphia 2012:1279-93.

4. Alvarado A. A practical score for the early diagnosis of acute appendicitis. Ann Emerg Med 1986;15(5):557-64. 
5. Lintula H, Kokki H, Pulkkinen J, Kettunen R, Gröhn O, Eskelinen M. Diagnostic score in acute appendicitis. Validation of a diagnostic score (Lintula score) for adults with suspected appendicitis. Langenbecks Arch Surg 2010;395:495-500.

6. Eskelinen M, Ikonen J, Lipponen P. Sex-specific diagnostic scores for acute appendicitis. Scand J Gastroenterol 1994;29(1):5966.

7. Markar SR, Karthikesalingman A, Falzon A, Kan Y. The diagnostic value of neutrophil: lymphocyte ratio in adults with suspected acute appendicitis. Acta Chir Belg 2010;110(5):5437.

8. Yazici M, Ozkisacik S, Oztan OM, Gursoy H. Neutrophil/ lymphocyte ratio in the diagnosis of childhood appendicitis. Turk J Pediatr 2010;52:400-3.

9. Lee JH, Park YS, Choi JS. The epidemiology of appendicitis and appendectomy in South Korea: National registry data. J Epidemiol 2010;20(2):97-105.

10. Dunn EL, Moore EE, Elerding SC, Murphy JR. The unnecessary laparotomy for appendicitis-can it be decreased? Am Surg 1982;48:320-3.

11. Kahramanca Ş, Özgehan G, Şeker D, Gökce EI, Seker G, Tunç $G$, et al. Neutrophil to lymphocyte ratio as a predictor of acute appendicitis? Ulus Travma Acil Cerrahi Derg 2014;20(1):1922.

12. Raungkaewmanee $S$, Tangjitgamol $S$, Manusirivithaya $S$, Srijaiprachoroen $S$, Thavaramara T. Platelet to lyphpcyte ratio as aprognostic factor for epithelial ovarian cancer. J Gynecol Oncol 2012;23(4):265-73.

13. Seretis C, Seretis F, Lagoudianakis E, Politou M, Gemenetzis G, Salemis NS. Enhancing the accuracy of platelet to lymphocyte ratio after adjustment for large platelet count: a pilot study in breast cancer patients. Int J Surgl Oncol 2012; Article ID 653608 .

14. Lee S, Oh SY, Kim SH, Lee JH, Kim MC, Kim KH, et al. Prognostic significance of neutrophil lymphocyte ratio and platelet lymphocyte ratio in advanced gastric cancer patients treated with FOLFOX chemotherapy. BMC Cancer 2013;13(1):350.

15. Kwon HC, Kim SH, Oh SY, Lee S, Lee JH, Choi HJ, et al. Clinical significance of preoperative neutrophil-lympocyte versus platelet-lympocyte ratio in patients with operable colorectal cancer. Biomarkers 2012;17(3):216-22.
16. Hailiang L, Xiaohuri DU, Peiming S, Chunhong X, Yingxin X, Rong L. Preoperative platelet-lympocyte ratio is an independent prognostic factor for resectable colorectal cancer. J South Med Univ 2013;33(1):70-3.

17. He W, Yin C, Guo G, Jiang C, Wang F, Qiu H, et al. Initial neutrophil lymphocyte ratia is superior to platelet lymphocyte ratio as an adverse prognostic and predictive factor in metastatic colorectal cancer. Med Oncol 2013;30(1):439.

18. Simith RA, Bosonnet L, Ghaneh P, Sutton R, Evans J, Healey $\mathrm{P}$, et al. The platelet-lymphocyte ratio improves the predictive value of serum CA 19-9 levels in determining patient selection for staging laparoscopy in suspected periampullary cancer. Surg 2008;143(5):658-66.

19. Bhatti I, Peacock O, Lloyd G, Larvin M, Hall RI. Preoperative hematologic markers as independent predictors of prognosis in resected pancreatic ductal adenocarcinoma: neutrophillymphocyte versus platelet-lymphocyte ratio. Am J Surg 2010;200(2):197-203.

20. Azab B, Shah N, Radbel J, Tan P, BhattV, Vonfrolio S, et al. Pretreatment neutrophil/lymphocyte ratio is superior to platelet lymphocyte ratio as a predictor of long-term mortality in breast cancer patients. Med Oncol 2013;30(1):432.

21. Wang D, Yang JX, Cao DY, Wan XR, Feng FZ, Huang HF, et al. Preoperative neutrophil-lymphocyte and platelet-lympocyte ratios as independent predictors of cervical stromal involvement in surgically treated endometroid adenocarcinoma. Onco Targ Ther 2013;6:211-6.

22. Azab B, Shah N, Akerman M, McGinn JT Jr. Value of platelet/ lymphocyte ratio as apredictor of all-cause mortality after nonST-elevation myocardial infarction. J Thromb Thrombolysis 2012;34(3):326-34.

23. Gary T, Pichler M, Belaj K, Hafner F, Gerger A, Froehlich H, et al. Platelet-to-lymphocyte ratio: A novel marker for critical limb ischemia in peripheral arterial occlusive disease patients. Plos One (www. plosone. org)2013;8(7): e67688.

24. Turkmen K, Erdur FM, Ozcicek F, Ozcicek A, Akbas EM, Ozbicer A, et al. Platelet-to-lymphocyte ratio better predicts inflammation than neutrophil-to-lymphocyte ratio in end-stage renal disease patients. Hemodial Int 2013;17(3):391-6. 